\title{
REASONS OR EFFECTS OF THE DEINDUSTRIALIZATION IN VISEGRAD COUNTRIES
}

\author{
*Dr. Dániel Kuttor \\ *Ágnes Hegyi-Kéri \\ University of Miskolc, Hungary
}

\begin{abstract}
The problems of the transition in the Visegrad countries on a national economic basis showed up on both social and economic levels, but it was the industry that had to face the most urgent challenges. Today, the economic answers given at the time of transformational recession are still influencing the economy of the Visegrad countries, its macro structural processes and the performance of its secondary sector. In post socialist countries the industrial sector's structure change was intensified by its peculiar economic policy and the delayed development. The literature of the deindustrialization determines the deindustrialization and the transformation of the economic structure as the natural concomitant of economic processes. Although we could distinguish a few reasons, which determine the type and the turbulence of the deindustrialization, our aim is to precisely examine in the Eastern European countries between 1999-2012 and if there any of the above mentioned reasons could play a role of the deindustrialization on regional level. Our research question is: after the political system change, in the examined countries, where and how fast was the decreasing in the number of the employees in the manufacturing sector? Could we group according to the effects on deindustrialization the regions of the Visegrad countries region? These groups have similarities, which help us to understand more precisely the process of the deindustrialization all over the world.
\end{abstract}

Keywords: Deindustrialization, Manufacturing Sector, Visegrad Countries

\section{INTRODUCTION}

“...it is possible that the economy is doomed to years of stagnation.” (Baumol, 1967)

The opposite process to industrialization is deindustrialization. Takács (2003) states that deindustrialization covers the decline, withering or failing of an industry. Saeger (1997) states that the most widely used indicator of deindustrialization is a declining number of employees in the manufacturing industry. Vidéki (2008) supports this when he claims that, despite industry being an indicator of technical progress, its significance is measured in close connection to the number of employees in industry (per regional unit, per thousand people, per number of persons in work). Abonyiné (2002) emphasizes that these indices do not indicate the level of advancement of industry but rather the process of industrialization. Taking Saeger (1997) as a basis, he summarizes below why experts prefer to use this indicator to quantify deindustrialization:

The proportion of employees in the manufacturing industry is a widely used indicator for measuring levels of industrialisation and quantifying economic advancement.

It is the most obvious indicator of the scale of the manufacturing industry, which the general public is also greatly interested in.

It focuses on changes in the cost items of different sectors, in particular input factors.

Any decline in the amount of investment affects the employment rate of the manufacturing industry since it has relatively high investment needs.

Clark claims that the process of deindustrialisation occurs at the intersection of industries. The Dictionary of Human Geography (2009) defines deindustrialisation as follows:

"Deindustrialisation is the permanent decline of industrial (in particular manufacturing industry) activity and capacity. These changes occur naturally as part of the economic cycle. However, when industrial 
production is joined by declining competitiveness and a drop in domestic and international demands, then deindustrialisation represents underdevelopment besides a lower rate of employment and an imbalance of payments." (p. 150)

In East Central European countries, the process is closely connected to the political changeover period when employment rates in industry spectacularly dropped. In Western European states the process started in the $60 \mathrm{~s}$ and the 70s. Since the process is still in progress, further longitudinal examination is needed. Parallel with deindustrialization there is an ongoing process of tertiarisation (i.e. the growing dominance of the tertiary sector) (Barta et al., 2008), a detailed discussion of which was first started in the United Kingdom. Singh (1977), who was among the first to seek to define correlations between deindustrialization and structural imbalance, claims that deindustrialization occurs when the manufacturing industry is unable to satisfy either domestic demands or create exports to the extent that it can satisfy the full employment rate needs of imports (at 'reasonable' exchange rates). He believes deindustrialization should be defined as being a consequence of structural imbalance, rather than its cause.

As opposed to this, we claim that deindustrialization has negative effects when jobs lost in industry are not substituted for by the tertiary sector and therefore unemployment increases. Rowthorn and Ramaswamy (1999) provide a comprehensive definition of the concept, as follows:

"Exports of the given country will shift from the dominance of industry to that of services, which will also induce a transfer of resources to other industries."

Based on this they argue that deindustrialization is a natural consequence of developed economies. Later researches started to focus on investigating the causes. In this article We examine what roles the internal endogen factors have in deindustrialisation, seeking to find out whether the organizational structure or the internal endogen structure had a more prominent influence on the Visegrad countries between 1999 and 2012. The employment structure can be traced back to the endogen factors like the local, country-specific facilities (natural resources, geographical location, infrastructure, migration differences, qualification, demographic tendencies, settlement structure) or are partially due to, on a more or less unrelated basis, structural factors.

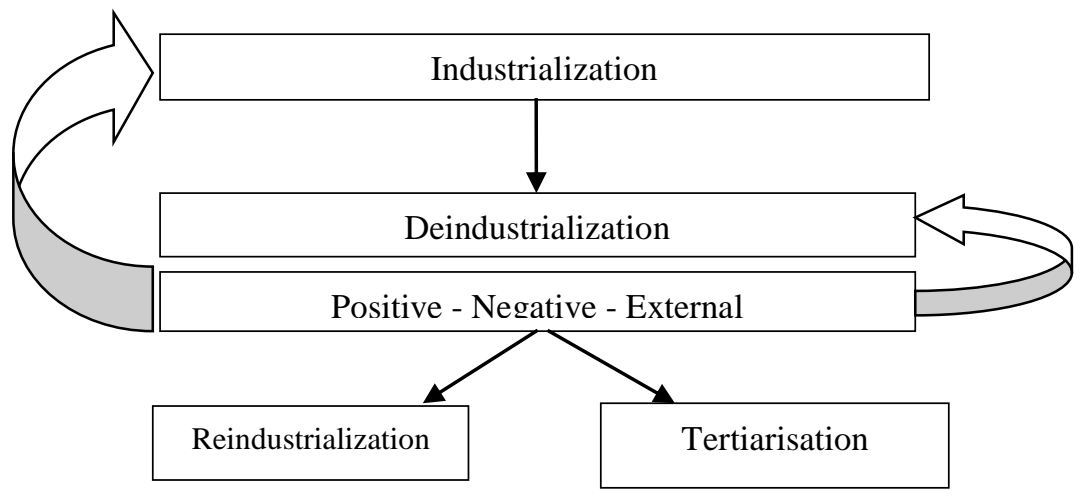

Figure 1.:The process of the deindustrialization Source: own work

We also aim to define the three types of deindustrialisation (positive, negative, external) in the regions, partly to offer further scopes of investigation on the inner factors within these regions.

When causes of deindustrialization are explored it is important to refer to the work of Rowthorn and Coutts (2006), besides the factor of structural imbalance mentioned before. After examining the role of trade in deindustrialization these authors concluded that there was a connection between deindustrialization and trade in the case of less developed economies. However, endogenous factors (like increasing productivity and declining consumption) have much greater significance. As a summary of the literature, the following explanations for deindustrialization are put forward: 
As a result of widening corporate specialisation needs, manufacturing industry corporations cut down on their employee headcount by outsourcing certain activities. However, the term 'lower numbers' is relevant only in a statistical sense; in fact the employees who are dismissed will be employed in the tertiary sector.

Lower relative prices in the manufacturing industry will cause a decline in the manufacturing industry compared to total consumption.

Higher productivity rates compared to the tertiary sector will imply less growth in employment in the manufacturing industry.

In the case of developed economies, trade may have a negative impact on the employment rates of the manufacturing industry, bringing forth an increased level of competitive constraints; labor intensive activities will decline due to the pressure of imports.

To put it crudely, the Visegrad countries became subjects of an economic experiment when they changed 'planned' economies for market economies. The transition has clearly induced major changes, both on a social and an economic level. Botos (2010) notes that the problems which are occurring as a result of the transformation affect all areas of national economies, yet it is the industry that has had to face the most pressing and profound transformation. During the transitional period a number of factors influenced industrial policy.

We list the most essential ones here, following Botos (2010):

Lack of previous experience - The Visegrad countries had to handle industrial issues (monostructure, constraints with industrialisation, facing new market needs, out-of-date technology) with no previous experience, in an economic environment of bankruptcy.

Time factors - Since changes affected the entire economy it is difficult to state when the transition period finished (if it has finished at all). Moreover, the time span of government intervention has also greatly varied.

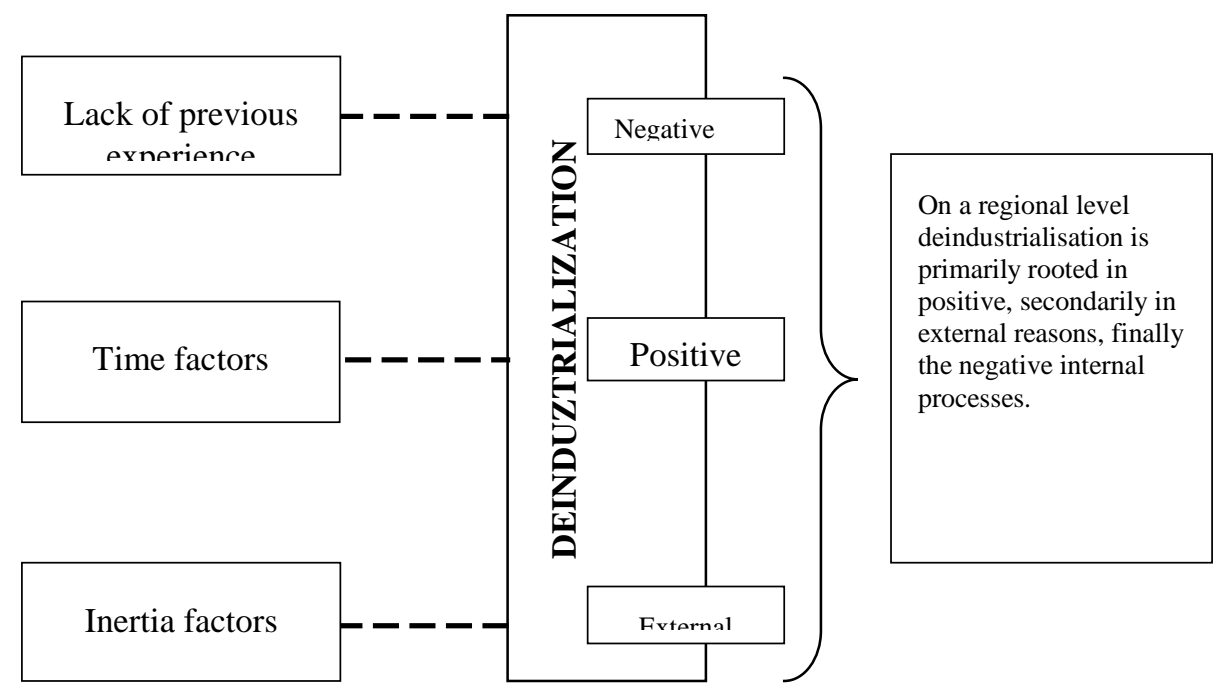

Figure 2.: The main research question of the article

Source: own construction

Inertia factors - Lux (2009) connects path dependency to the crisis apparent with industrial regions. In a traditional sense, path dependency means that the scope of decisions possible at a given moment cannot be independent of the history of the given region. In many cases circumstances which affect a present decision act as 'inertia' in certain regions, hindering development. 


\section{DEINDUSTRIALISATION OR REINDUSTRIALISATION ON REGIONAL LEVEL ON VISEGRAD COUNTRIES}

Both the ratio and the number of all people employed in the industrial sector dropped in all Hungarian sectors. The process is the most prominent in Közép-Magyarország and Dunántúl, where a continuous decline of over $10 \%$ could be observed. On a regional scale we can talk about an absolute deindustrialisational process between 1999 and 2012 in Hungary: between 1999 and 2008 in Közép-Hungary and on the Észak-Alföld a relative deindustrialisation process began, whereas in the other regions the number of industrial employees declined as well as their percent in the full employment rate. Between 1999 and 2012 the reduction in ratio of the industrial workers can be observed in 8 regions of Poland, and in 8 other regions an increase in the ratio of industrial workers is prominent in the same time slot. This increase did not exceed $8 \%$ in any region, and in the capital a more than $10 \%$ decline took place. In one region (Zachodniopomorskie) absolute deindustrialisation took place between 1999 and 2012, while relative deindustrialisation was characteristic to the Malopolskie region, Dolnoslaskie region, Opolskie region, Warminsko-Mazurskie region and Kujawsko-Pomorskie region.

\section{Table 1.:Categories based on the changes in the number and ratio of industrial} workers

\begin{tabular}{|c|c|c|c|}
\hline & $\begin{array}{c}\text { Number of industrial workers } \\
\text { between 1999-2012 }\end{array}$ & $\begin{array}{c}\text { Ratio of } \\
\text { industrial workers by } \\
2012(1999=100 \%)\end{array}$ & $\begin{array}{c}\text { Number of all employed } \\
\text { between } 1999-2012\end{array}$ \\
\hline Absolute deindustrialisation & decrease & decrease & decrease \\
\hline \multirow{3}{*}{ Relative deindustrialisation } & decrease & decrease & increase \\
\cline { 2 - 4 } & increase & decrease & decrease \\
\hline \multirow{2}{*}{ Virtual industrialisaton } & decrease & increase & decrease \\
\hline increase & increase & decrease & increase \\
\hline (Re) industrialisation & increase & increase & increase \\
\hline
\end{tabular}

Source: own construction

In the time scope of the study the ratio of the industrial workers increased in one region in the Czech Republic. Between 1999-2012 relative deindustrialisation took place in five Czech regions: Praha, Severozápad, Jihovýchod, Strední Morava and Moravskoslezsko. There was only one absolute deindustrialisation: Severovýchod. In the Strední Cechy region quasi industrialisation took place, whereas in the Jihozápad region (re)industrialisation occured.

In Slovakia the 2008 recession cut the percent growth of industrial workers short, in one region, in Stredné Slovensko relative deindustrialisation took place between 1999-2012, in other words the number of industrial workers declined. Východné Slovensko is a case of quasi industrialisation, as the number of industrial workers declined in the research period. In the other regions' (Bratislavský kraj, Západné Slovensko) (re)industrialisaton took place.

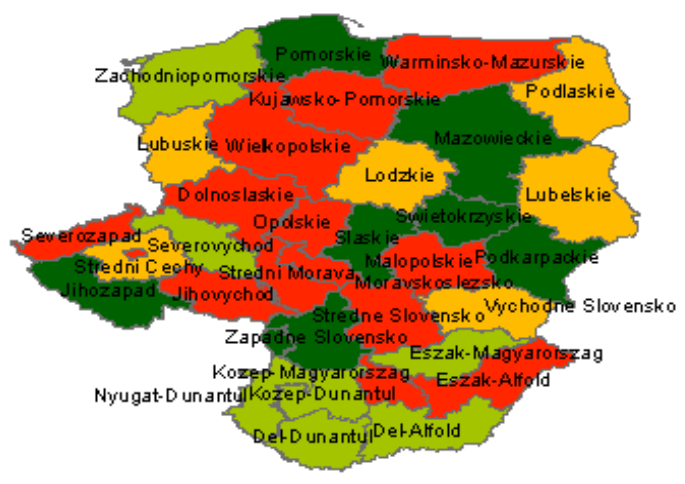

\begin{tabular}{|l|l|}
\hline Absolute deindustrialisation & light green \\
\hline Relative deindustrialisation & red \\
\hline Virtual industrialisaton & orange \\
\hline$(\mathrm{Re})$ industrialisation & green \\
\hline
\end{tabular}

Figure 3: The categories based on the number and percent of industrial workers Source: own work 
On a regional level in the Visegrad countries we can talk about absolute and relative deindustrialisation on a regional and economic level as well as quasi industrialisation and (re)industrialisation between 1999 and 2012. Between 1999 and 2012 Hungary and the Czech Republic displayed deindustrialisation, whereas in Poland and Slovakia quasi industrialisation took place at the same time. The recession in 2008 interfered with the development path of two regions (Közép-Dunántúl and the Észak-Alföld); overall we can identify absolute deindustrialisation in five Hungarian regions between 1999 and 2012. My goal is to distinguish the three types of deindustrialization (positive, negative and external) in each region. In the next table I demonstrate how the ratio of the industrial workers changed in each region. Based on the data in the table we can conclude that in 26 out of 35 regions included in the survey the ratio of industrial workers declined, $74 \%$ of the surveyed regions were affected by deindustrialisation. In Hungary and the Czech Republic all regions, whereas in Poland 9 and in Slovakia 3 regions were affected.

In the following, we used the shift-share analysis to investigate the hypothesis on regional level between 2000-2007 in the Visegrad countries. The change in the regional economic structure was measured using the number of employees. The shift-share analysis made this measurement possible, which was first used by Perloff et al. (1960). Since then, this method has also been included in most of the regional research handbooks (Sikos, 1984). Many people have used this method to analyze the changes in employment structure, both macro and regional (county) level (Csugány - Máté, 2009; Lőcsei 2004). Similar international studies were done by Batóg-Batóg (2007) and Jonuschat-Knoll (2008) in Czech regions, examining different time frames. It was calculated for each country whether the expansion in employment was faster or slower than the average of the Visegrad Four ( $\mathrm{Si}$ ), which was broken down into two, above-mentioned local ( $\mathrm{Sr}$ ) and structural (Sa) factors.

\section{Table 2: The result of the shift-share analysis in the Visegrád countries on regional level betwween 1999-2012}

\begin{tabular}{|c|c|c|}
\hline Típus & structural $>$ local & local> structural \\
\hline $\begin{array}{l}\text { Positive structural and positive local factor, } \\
\text { a higher than average employment growth }\end{array}$ & $\begin{array}{l}\text { (1) Mazowieckié, (2) Slaskie, } \\
\text { (3) Lubuskie, (4) } \\
\text { Dolnoslaskie, (5) Pomorskie, }\end{array}$ & (1) Közép-Magyarország \\
\hline $\begin{array}{l}\text { Positive structural and negative local factor, } \\
\text { a higher than average employment growth }\end{array}$ & (1) Praha & \\
\hline $\begin{array}{l}\text { Negative structural and positive local factor, } \\
\text { a higher than average employment growth }\end{array}$ & $\mathrm{X}$ & $\begin{array}{l}\text { (1) Západné Slovensko, (2) Východné } \\
\text { Slovensko, (3) Střední Čechy, (4) Észak- } \\
\text { Alföld, (5) Swietokrzyskie }\end{array}$ \\
\hline $\begin{array}{l}\text { Positive structural and negative local factor, } \\
\text { a below-average employment growth }\end{array}$ & $\mathrm{X}$ & $\begin{array}{l}\text { (1) Kujawsko-Pomorskie, (2) Warminsko- } \\
\text { Mazurskie, (3) Bratislavský kraj, (4) } \\
\text { Severozápad, (5) Moravskoslezsko, (6) } \\
\text { Lódzkie, (7) Zachodniopomorskie }\end{array}$ \\
\hline $\begin{array}{l}\text { Negative structural and positive local factor, } \\
\text { a below-average employment growth }\end{array}$ & $\begin{array}{l}\text { (1) Podlaskie, (2) Jihozápad, } \\
\text { (3) Jihovýchod }\end{array}$ & $\mathrm{X}$ \\
\hline $\begin{array}{l}\text { Negative structural and negative local } \\
\text { factor, a below-average employment growth }\end{array}$ & $\begin{array}{l}\text { (1) Lubelskie, (2) } \\
\text { Podkarpackie, (3) Közép- } \\
\text { Dunántúl, } \\
\text { (4) Nyugat-Dunántúl, (5) } \\
\text { Dél-Alföld }\end{array}$ & $\begin{array}{l}\text { (1) Severovýchod, (2) Střední Morava, (3) } \\
\text { Dél-Dunántúl, (4) Észak-Magyarország, } \\
\text { (5) Stredné Slovensko, (6) Malopolskie (7) } \\
\text { Wielkopolskie, (8) Opolskie }\end{array}$ \\
\hline
\end{tabular}

Source: Accoding to Eurostat database own calculation

All three factors can adopt positive or negative values, and the studied countries can be grouped accordingly (highlighting that local or structural factors dominated the expansion in employment). Positive Sa means, that the rate of employment increased more than the average of the Visegrad Four. In this case, we can talk about a positive structural change and competitive advantage. When $\mathrm{Sr}$ is positive, infrastructure, education, migration and demographic trends (local factors) have a positive impact on employment growth. In the following, we examine the influencing role of the various factors in the different regions. We highlighted those scenarios that hypothetically speaking cannot come into being. In my interpretation negative deindustrialisation means that the service sector could not compensate for the decline in the industry. On the whole employment numbers decreased in the region, which phenomenon can be traced back to inner factors rather than structural change. WE assume both factors influence employment processes in negative deindustrialization. Observe in the following table how the decline in the number of people employed by the 
industry (1999=100\%) (considering absolute numbers of the secondary sector only) was followed by a relapse, stagnation or a small-scale growth in the employment potential in the service sector. Inner local factors had a bigger influence on the drop in employment.

\section{Table 3 Negative deindustrializational regions in the Visegrad countries between 1999-2012}

\begin{tabular}{|c|c|c|c|c|}
\hline & $\begin{array}{c}\text { Negative deindustrializational } \\
\text { region }\end{array}$ & $\begin{array}{l}\text { Decrease or small-scale } \\
\text { growth in number of } \\
\text { personnel employed in } \\
\text { the secondary sector }\end{array}$ & $\begin{array}{c}\text { Employment as } \\
\text { a whole } \\
\text { decreased }\end{array}$ & $\begin{array}{c}\text { Local } \\
\text { factors having a bigger } \\
\text { influence on employment } \\
\text { changes than structural factors }\end{array}$ \\
\hline 1. & Dél-Dunántúl & $104 \%$ & $96 \%$ & $-17>-3,89$ \\
\hline 2. & Észak-Magyarország & $100 \%$ & $95 \%$ & $-30>-2,7$ \\
\hline 3. & Malopolskie & $111 \%$ & $96 \%$ & $-136,5>-15,4$ \\
\hline 4. & Wielkopolskie & $111 \%$ & $96 \%$ & $-144,7>-22,4$ \\
\hline 5. & Zachodniopomorskie & $98 \%$ & $97 \%$ & $-92,2>32,7$ \\
\hline 6. & Opolskie & $103 \%$ & $86 \%$ & $-78,5>-9,4-$ \\
\hline 7. & Warminsko-Mazurskie & $94 \%$ & $96 \%$ & $78,1>16,4$ \\
\hline
\end{tabular}

Source: Own calculations based on Eurostat data

A different regional pattern in negative deindustrialisation can be observed between 1999-2008, mostly characteristic to Hungary. The recession definitely intensified the negative deindustrialization processes. Studies trace the external deindustrialisation back to changes in trade structure and external shocks, which means the decline in export-producing companies due to the recession within the Visegrad countries.

Table 4.: External deindustrializational regions in the Visegrad countries between 19992012

\begin{tabular}{|l|l|l|l|l|}
\hline & $\begin{array}{c}\text { External } \\
\text { deindustrialization } \\
\text { al regions }\end{array}$ & $\begin{array}{l}\text { Growth in } \\
\text { employment } \\
\text { in the srvice } \\
\text { sector }\end{array}$ & $\begin{array}{l}\text { Decline in } \\
\text { total } \\
\text { employment }\end{array}$ & $\begin{array}{l}\text { Structural changes having more } \\
\text { negative influence on employment } \\
\text { changes than local factors }\end{array}$ \\
\hline 1. & Közép-Dunántúl & $105 \%$ & $99 \%$ & $-8,1>-7,5$ \\
\hline 2. & Nyugat-Dunántúl & $110 \%$ & $100 \%$ & $-8,87>-1,79$ \\
\hline 3. & Dél-Alföld & $112 \%$ & $98 \%$ & $-13,50>-2,99$ \\
\hline 4. & Jihovýchod & $113 \%$ & $102 \%$ & $-11>1,6$ \\
\hline
\end{tabular}

Source: Own calculations based on Eurostat data

Surprisingly the recession mostly influenced the employment growth in the Hungarian regions. In the case of external deindustrialization the changes in economic structures had a negative impact on employment tendencies, with declining industrial employment potential the service sector cannot compensate for the difference. WE consider those processes cases of positive deindustrialization where the economic structure transforms in a way that the service sector can increase its employment potential and thus increase full employment in the field after the recline of industry. This growth is primarily based on the economic structure. In my opinion external factors, such as spiralling recession can cause deindustrialization when the decline in employment is mostly due to structural changes despite the increase in service sector employment. 
Table 5.:Positive deindustrializational regions in Visegrad countries between 1999-2012 Source: own calculations based on Eurostat data

\begin{tabular}{|l|l|c|c|c|}
\hline & $\begin{array}{c}\text { Positive } \\
\text { deindustrializational } \\
\text { regions }\end{array}$ & $\begin{array}{c}\text { Employment } \\
\text { in service } \\
\text { sector } \\
\text { growth }\end{array}$ & $\begin{array}{c}\text { Total } \\
\text { employment } \\
\text { growth }\end{array}$ & $\begin{array}{c}\text { Local factors having bigger } \\
\text { influence on employment than } \\
\text { structural changes }\end{array}$ \\
\hline 1. & Közép-Magyarország & $122 \%$ & $109 \%$ & $41>39$ \\
\hline 2. & Észak-Alföld & $111 \%$ & $105 \%$ & $18,20>-2,65$ \\
\hline 3. & Severovýchod & $110 \%$ & $102 \%$ & $-20>-10$ \\
\hline 4. & Severozápad & $105 \%$ & $100 \%$ & $-21,9>1,8$ \\
\hline 5. & Stř́ední Morava & $110 \%$ & $102 \%$ & $-12,1>-6$ \\
\hline 6. & Moravskoslezsko & $113 \%$ & $105 \%$ & $-12,5>0,1$ \\
\hline 7. & Bratislavský kraj & $108 \%$ & $103 \%$ & $-40,14>18,40$ \\
\hline 8. & Kujawsko-Pomorskie & $106 \%$ & $101 \%$ & $-55,5>3,3$ \\
\hline 9. & Stredné Slovensko & $124 \%$ & $109 \%$ & $-1,17>-0,89272$ \\
\hline
\end{tabular}

WE displayed the types of impounded deindustrialization on the following map. The regions of negative deindustrialization are coloured yellow, the regions of positive deindustrialization are red and the regions of external deindustrialization are green. Regions of positive deindustrialization are the Czech Republic and the Eastern parts of Hungary. The regions of negative deindustrialization are situated on the Western part of Poland.

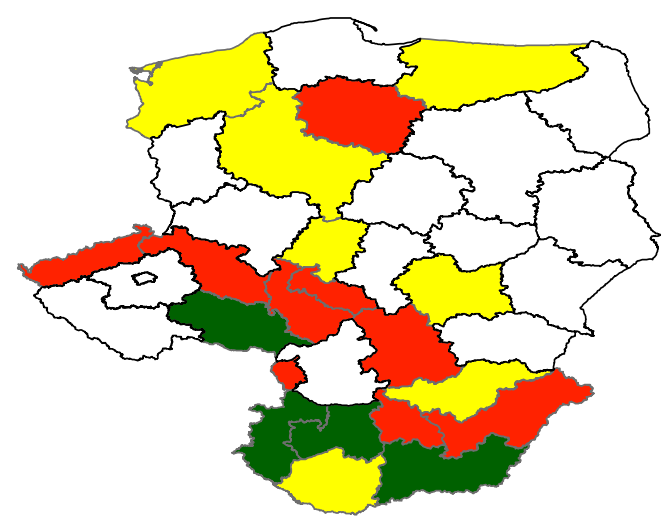

\begin{tabular}{|l|l|}
\hline Positive deindustrializational regions & red \\
\hline Negative deindustrializational regions & orange \\
\hline External deindustrialization regions & green \\
\hline
\end{tabular}

\section{Figure 3.: The three types of deindustrialization in the Visegrad countries Source: own editing}

My hypothesis was proven right: all three types of deindustrialization are present in the Visegrad countries between 1999-2012.

\section{CONCLUSION}

In the period between 1999-2012 deindustrialization could be observed in half of the regions of the Visegrad countries. Deindustrialization still influences the regions development to this day and provides a basis of examination into the inner workings of deindustrialization. 7 out of 18 regions displayed deindustrialization, 3 external deindustrialization and 9 regions negative deindustrialization. External negative and external deindustrialization is the consequences of the deindustrialization process, which have different effects on the labour market, and different effect on overall employment. The classification above can help us understand as well as manage the effects of deindustrialization on the labour force. 


\section{REFERENCES}

Abonyiné Palotás J. (2002): Az általános iparföldrajz alapjai. (The general industry on a geographical basis) pp. 127-164. In.: Tóth J. (editor.): I. GENERAL social geography Dialogue Campus Press, Budapest and Pécs. pp.484

Barta Gy.;Czirfusz M.; Kukely Gy. (2008): Újraiparosodás a nagyvilágban és Magyarországon. (Reindustrialization in the World and Hungary) Space and Society, 2008. 4. pp. 1-21.

Batóg B.; Batóg J. (2007): Shift-Share Analysis of Employment growth within the EU countries in 19992005. Available at www.mikro.univ.szczecin.pl/bp/index.php? $\mathrm{a}=\mathrm{h} 68 \mathrm{f} 3$ (Quoted 12. 5. 2013.)

Baumol W. (1967): Macroeconomics of Unbalanced Growth: The anatomy of urban crisis, American Economic Association American Economic Review, Vol. 57, No. 3 (Jun., 1967), pp. 415-426

Botos B. (2010): Az iparpolitika metamorfózisa. (The metamorphosis of industrial policy) L'Harmattan Edition, College of King Zsigmond . pp. 313

Gregor, D. - Johnston R. - Pratt G. - Watts M. - Whatmore S. (2009): The Dictionary of Human Geography, 5th Edition ISBN: 978-1-4051-3288-6, pp.1072 April, Wiley-Blackwell

Jonuschat H.;Knoll M. (2008): Regional transformation processes in Central and Eastern Europe.

Contributions of the TRANSFOR(U)M network members. Bibliografische Information der Deutschen

Bibliothek. download: http://dnb.ddb.de. 2014.02.12

Lőcsei H. (2004): A foglalkoztatás ágazati és regionális dimenzióinak kapcsolata az ezredvégi Magyarországon.( The sectoral and regional dimensions of the employment relationship at the end of the millennium in Hungary) in: Nemes Nagy J. (editor): Térségi és települési növekedési pályák Magyarországon. (Urban and regional development pathways in Hungary.) (Regional Science Studies 9.) ELTE Department of Regional Geography - MTA-ELTE Research Group of Regional Science, pp. 43-58.

Lux G. (2009): Az ipar hagyományos terei: a régi ipari térségek. (The industry standard spaces of the old industrial regions) In: Space and Society. 23.vol. 2009/4.pp. 45-60

Perloff, H.S.; E.S. Dunn - Jr., E.E. Lampard - R.F. Muth (1960): Regions, Resources and Economic Growth, Part III. Baltimore: Johns Hopkins University Press.

Rowthorn, R. ; Ramaswamy (1999): Growth, Trade and Deindustrialisation, IMF Staff Papers 46.1,pp.18-4.

Rowthorn, R. ;Coutts K. (2006): Deindustrialisation and the Balance of Payments in Advanced Countries", updated version of a paper published in Cambridge Journal of Economics September 2004.

Saeger, S. (1997): Globalization and Deindustrialization: Myth and Reality in the OECD. Weltwirtschaftliches Archly Review of World Economics 133 (4): pp.579-607.

Singh, A (1977): UK Industry and the World Economy: A Case of Deindustrialisation, Cambridge Journal of Economics, 1.2 , pp.113-36.

Sikos T. (1984): Application of mathematical and statistical methods for spatial research. Geographical Studies, No. 19, Academic Press, Budapest.

Csugány J.; Máté D. (2013): A munkatermelékenységben bekövetkezett szektorális változások technológiaintenzív megközelítésben. (Changes in the labour productivity in connection of sectoral changes from the aspect of technology-intensive approach.) In.: Regional Statistics, 2013, 53 (4): pp.340-353.

Takács Z. (2003): Az ipar leépülésének jelensége néhány külföldi példán In.: Észak-Magyarország gazdasági helyzete, 1990-2001 (The phenomenon of industrial degradation of some foreign examples In.: North Hungary's economic situation from 1990 to 2001.) Editor:

Tóth I. János, Hungarian Chamber of Commerce for Economic and Business Research Institute, Bp., 2003. pp.3-26

Vidéki I. (2008): Fejezetek ipar- és közlekedésföldrajzból. (Chapters from industrial and transportation geography) ELTE EötvösEdition, pp. 311 